\title{
Suppression of Seedling Damping-Off Caused by Pythium ultimum, P. irregulare, and Rhizoctonia solani in Container Media Amended with a Diverse Range of Pacific Northwest Compost Sources
}

\author{
Steven J. Scheuerell, Dan M. Sullivan, and Walter F. Mahaffee
}

First author: Department of Botany and Plant Pathology, and second author: Department of Crop and Soil Science, Oregon State University, Corvallis 97331; and third author: U.S. Department of Agriculture-Agriculture Research Service, Horticulture Crops Research Laboratory, 3420 NW Orchard Ave., Corvallis, OR 97330.

Accepted for publication 29 November 2004.

\begin{abstract}
Scheuerell, S. J., Sullivan, D. M., and Mahaffee, W. F. 2005. Suppression of seedling damping-off caused by Pythium ultimum, P. irregulare, and Rhizoctonia solani in container media amended with a diverse range of Pacific Northwest compost sources. Phytopathology 95:306-315.

Suppression of seedling damping-off disease caused by Pythium spp. and Rhizoctonia solani is a potential benefit of formulating soilless container media with compost. Thirty-six compost samples from Pacific Northwest commercial composting facilities were analyzed for a number of physical, chemical, and biological properties, including suppression of damping-off caused by Pythium ultimum, P. irregulare, and R. solani. The samples were produced from diverse feedstocks and composting technol-

ogies; this was reflected in a large degree of variability in the measured properties. When mixed with sphagnum peat moss and inorganic aggregates, $67 \%$ of the compost samples significantly suppressed $P$. irregulare damping-off of cucumber, 64\% suppressed $P$. ultimum damping-off of cucumber, and $17 \%$ suppressed damping-off of cabbage caused by $R$. solani. Suppression of Pythium damping-off was related to the potential of compost to support microbial activity and a qualitative index of ammonia volatilization. Suppression of Rhizoctonia damping-off was not related to any one compost factor. Currently available compost products potentially could provide commercially acceptable control of damping-off caused by Pythium spp., but it is necessary to fortify composts with microbial antagonists for the control of $R$. solani.
\end{abstract}

The use of sphagnum peat-based container media for germinating seedlings is a standard greenhouse industry practice (19). With peat-based container media, fungicides are used routinely in commercial greenhouses to manage damping-off disease of seedlings, commonly caused by Pythium spp. and Rhizoctonia solani (42). Although some peat sources suppress damping-off $(44,46)$, the suppressive effect is variable and short in duration depending on the degree of peat decomposition $(2,25)$.

Damping-off disease caused by Pythium spp. and $R$. solani can be suppressed by incorporating compost into soilless container media $(11,21,22,29)$. Suppression of damping-off caused by Pythium spp. has been associated with compost made from a broad range of raw feedstocks, with suppression frequently related to the level of microbial activity and biomass in compostamended container media $(5,6,10,16,17,29,34,40,45)$. Suppression of damping-off caused by $R$. solani in compost-amended container media most frequently has been related to the presence of specific microbial antagonists $(28,30,31,36)$ and not to the total level of microbial activity or biomass. However, Diab et al. (11) recently reported that suppression of Rhizoctonia damping-off in impatiens was related in part to increased microbial activity associated with a soilless container medium amended with composted swine-waste.

The majority of reports on the use of compost-amended container media for plant disease suppression have focused on a specific source of compost, while fewer studies have surveyed

Corresponding author: W. F. Mahaffee

E-mail address: mahaffew@ @science.oregonstate.edu

DOI: 10.1094/PHYTO-95-0306

This article is in the public domain and not copyrightable. It may be freely reprinted with customary crediting of the source. The American Phytopathological Society, 2005. multiple compost types produced at various locations $(10,13,38)$. Craft and Nelson (10) found a strong correlation between microbial activity and damping-off suppression of Pythium graminicola on creeping bent grass across a wide variety of compost types. Erhart and Burian (13) found that suppression of P. ultimum across 21 composts, made primarily from source-separated household organic waste, correlated to compost organic matter content. Ringer (38) examined three types of manure-based compost and found that suppression of $P$. ultimum on cucumber seedlings increased from poultry litter to steer manure to dairy manure compost, whereas $R$. solani suppression was not related to the type of compost.

Compost-amended container media have not been adopted widely by the Pacific Northwest commercial greenhouse industry (S. Scheuerell, personal observation). For this geographical region, there is a lack of information on compost quality characteristics, particularly compost physical, chemical, and biological properties, including the potential for suppressing damping-off disease. Goals of this study were to develop a database of physical, chemical, and biological properties of diverse composts produced from various feedstocks at commercial facilities in the Pacific Northwest; determine whether damping-off caused by $P$. ultimum, $P$. irregulare, and $R$. solani were suppressed by container media amended with these composts; determine if suppression of damping-off was related to specific physical, chemical, and biological properties of compost; and determine whether suppression of $R$. solani was related to total microbial activity in composts.

\section{MATERIALS AND METHODS}

Compost sample collection. In all, 30 compost samples were collected at commercial compost facilities between May and 
September 2000; 28 samples were from western Oregon and 2 samples were from western Washington. Screened compost that was considered ready for sale by the facility operator was sampled. Five cores of compost, each approximately $1.1 \mathrm{~m}$ deep, were shoveled into a 75-liter plastic bin. Compost was mixed in the bin with the shovel, then covered and transported to the laboratory. Compost feedstocks, pile dimensions, turning frequency, compost age, and additional processing and process control information were collected for each sample. Compost was screened to pass a 6.4-mm mesh screen. Laboratory analyses were completed and damping-off assays started within $24 \mathrm{~h}$ of sampling. Samples then were stored at $4^{\circ} \mathrm{C}$. Six additional samples also were included in this study. Of these, four were collected in Oregon prior to the study and had been stored at $4{ }^{\circ} \mathrm{C}$ for 2 to 8 months, then held at room temperature for 3 days before use. One sample was mailed from Washington, and one was a bagged product from Montana. These samples were processed as described above.

$\boldsymbol{P}$. ultimum and $\boldsymbol{P}$. irregulare damping-off assay. A modified $P$. ultimum cucumber seedling bioassay was used (6). Inoculum of P. ultimum (isolated from corn roots, Willamette Valley, OR; provided by B. Hoinacki, Oregon State University) and P. irregulare (provided by J. Marlow; U.S. Department of Agriculture-Agricultural Research, Corvallis, OR) were produced on Ko and Hora's (27) soil and chopped potato medium, dried, and sieved. Particles that passed through a $1-\mathrm{mm}^{2}$ grid and were retained on a $0.25-\mathrm{mm}^{2}$ grid were used. Container media were made by mixing equal volumes of compost and a commercial peat-perlite medium (Sunshine Mix \#1; Sun Gro Horticulture, Inc., Vancouver, B.C., Canada). The commercial medium contained approximately $85 \%$ peat moss by volume. Inoculum of either $P$. ultimum or $P$. irregulare $(1.0 \mathrm{~g} /$ liter $)$ was mixed with 2 liters of container medium in a plastic bag then, dispersed into six $400-\mathrm{ml}^{2}$ plastic nursery pots. Each experiment had infested and pathogen-free peat-perlite treatments as standards. Each pot was sown $1 \mathrm{~cm}$ deep with eight cucumber seed (Cucumis sativus 'Marketmore 76'), then watered to capacity with tap water. Replicate pots were placed on separate plastic trays; the trays served as experimental blocks. A large, clear plastic bag was inflated and sealed around each tray to simulate a germination room and maintain even moisture in the pots. The trays were placed in a $20^{\circ} \mathrm{C}$ growth chamber with a 16-h photoperiod. At 3 and 6 days after planting (DAP), each bagged tray was vented to minimize changes in the atmosphere within the sealed trays. At 9 DAP, pots were assessed for the number of healthy cucumber seedlings. A seedling was classified as healthy if it was growing normally and had no symptoms of infection. Symptoms and signs on diseased seedlings included water-soaked or yellowing stem, wilted cotyledons, stem lesions leading to seedling collapse, and white mycelia covering any portion of the seedling.

$\boldsymbol{R}$. solani damping-off assay. $R$. solani AG-4 (poinsettia isolate RS3; provided by Marc Cubeta) was cultured on short-grain brown rice that had been soaked in water for $12 \mathrm{~h}$, then autoclaved in 1-liter flasks on three consecutive days for $55 \mathrm{~min}$. Three 6-mm-diameter agar disks containing actively growing hyphae were transferred aseptically from plates of potato dextrose agar into the rice flasks and incubated in darkness at $22^{\circ} \mathrm{C}$. After 3 weeks, the rice was transferred to a sterile box, partially covered, and dried over a period of 3 days in a laminar flow hood. Dried rice was ground and sieved. The $0.50-$ to $1.00-\mathrm{mm}$ size fraction was retained for use as inoculum. Inoculum was stored at $4^{\circ} \mathrm{C}$ until used.

Compost-amended container medium was prepared by mixing 2 liters of compost with 1.6 liters of light sphagnum peat (Lakeland Peat Moss Ltd., Hubbard, OR) and 0.4 liters of vermiculite (5:4:1, vol/vol) in a plastic bag. Inoculum of $R$. solani $(0.75 \mathrm{~g} / \mathrm{liter})$ was mixed thoroughly into the container medium. Infested medium was distributed into four replicate plug tray sections with
50 cells ( 5 by 10 cells). The sections were cut from 200-cell trays (each cell was 2.0 by 2.0 by $4.5 \mathrm{~cm}$; Landmark Plastic Corp., Akron, $\mathrm{OH}$ ). All cells were sown with one cabbage seed (Brassica oleracae 'Cheers'), covered with $3 \mathrm{~mm}$ of fine vermiculite, and watered to capacity with tap water. In each experiment, peat and vermiculite container media $(4: 1, \mathrm{vol} / \mathrm{vol})$, with and without $R$. solani inoculum, were included as standards. The plug tray sections were placed on a greenhouse bench in a randomized complete block design. The greenhouse was maintained at $\approx 23^{\circ} \mathrm{C}$ under natural light that was supplemented as needed to maintain a 16-h photoperiod with $400 \mathrm{~W}$ high pressure sodium lamps (P.L. Lighting Systems, Beamsville, Ontario, Canada). Trays were watered with tap water as needed. At 14 DAP, 24 plug cells (inner three by eight rows) of each tray section were assessed for disease incidence. The number of healthy seedlings, defined as having no visible lesions above the media-air interface, was counted (0 to 24).

Compost sources that initially suppressed $R$. solani dampingoff were assayed again to determine if suppression was consistent. After completion of the damping-off assays, three compost sources that suppressed $R$. solani in three of three bioassays were sampled again and processed as described. A portion of these compost samples and peat/vermiculite media were heated individually with aerated steam to determine whether disease suppression was significantly reduced by heating. Pressurized steam and ambient air were proportioned into a modified metal cabinet to maintain either 60 or $88^{\circ} \mathrm{C}$. The samples were heated in perforated metal pans and maintained at the target temperature for 30 min once the center of the heating material had attained either 60 or $88^{\circ} \mathrm{C}$. After cooling to ambient temperature, the material was used immediately in the Rhizoctonia damping-off assay, modified to include heated and nonheated material with and without the pathogen to ensure that heating did not induce phytotoxicity.

After it was determined that the suppressive properties of one compost (dairy fir-bark) (Table 1, no. 5) were not affected by steam treatment, unheated compost was inoculated with Trichoderma hamatum (T 382) (31) to determine whether suppression could be biologically enhanced. Four liters of compost was amended with $\mathrm{T} 382$ (5 g of colonized millet seeds/liter compost) 5 days before mixing the compost with peat and vermiculite (5:4:1 vol/ $\mathrm{vol})$. Another 4 liters of compost was amended with $\mathrm{T}$ 382 as described just prior to mixing with peat and vermiculite (5:4:1 vol/vol). The $\mathrm{T}$ 382-amended treatments were compared with compost not amended with $\mathrm{T} 382$ in the Rhizoctonia damping-off assay.

Compost physical properties. Compost temperature was recorded at 30- and 120-cm depths from three locations in the compost pile at the time of sampling. Water content was determined by drying $50 \mathrm{~g}$ of compost for $36 \mathrm{~h}$ at $70^{\circ} \mathrm{C}$ in a forced-air oven (32). Particle size distribution (wet weight basis) was determined by passing 1,000 $\mathrm{g}$ of compost through 12.8-, 6.4-, 4-, and 2-mm mesh sieves.

Compost chemical properties. Compost $\mathrm{pH}$ was determined from a saturated paste with a portable $\mathrm{pH}$ meter (model 150; IQ Scientific Instruments, San Diego, CA) and electrical conductivity (EC) was determined from a 2:1 ( $\mathrm{vol} / \mathrm{vol})$ mixture of distilled water:compost (32) using a portable EC meter (model 933100; Hanna Instruments, Woonsocket, RI).

Chemical analyses of compost samples were performed by the Oregon State University Central Analytical Laboratory using modified soil and plant analysis methods (14). Ammonium-N and $\mathrm{NO}_{3}-\mathrm{N}$ were extracted from fresh (not dried) compost using $2 \mathrm{M}$ $\mathrm{KCl}$. Ammonium-N and $\mathrm{NO}_{3}-\mathrm{N}$ were determined using automated colorimetric methods. Compost was dried at $60^{\circ} \mathrm{C}$ and ground to pass through a $2-\mathrm{mm}$ screen prior to other chemical analyses. Total $\mathrm{C}$ and $\mathrm{N}$ were determined using high-temperature furnace oxidation and subsequent direct measurement of $\mathrm{C}$ and $\mathrm{N}$ by an infrared detector (LECO Instruments Model CNS 2000; LECO Instruments, St. Joseph, MI). Other elements were deter- 
mined after extraction or digestion using an inductively coupled plasma spectrophotometer (ICP). Exchangeable bases ( $\mathrm{Ca}, \mathrm{Mg}$, and $\mathrm{K}$ ) were extracted from the compost sample with $1 \mathrm{M}$ ammonium acetate at $\mathrm{pH} 7$. For total $\mathrm{P}$ analysis, the sample was digested in acid $\left(0.03 \mathrm{~N} \mathrm{NH}_{4} \mathrm{~F}\right.$ and $\left.0.025 \mathrm{~N} \mathrm{HCl}\right)$. Iron and $\mathrm{Mn}$ were extracted with a chelate solution (0.025 M DTPA).

An index of compost ammonia volatilization was determined with Solvita Compost Maturity Test kits (Woods End Research Laboratory, Inc., Mt. Vernon, ME) according to the manufacturer's instructions (47). A reading of " 5 " indicated very low $\mathrm{NH}_{3}$, and the quantity of ammonia detected increased as the Solvita $\mathrm{NH}_{3}$ test score decreased from 5 to 1 (47).

Compost respiration. Compost respiration was assessed with Solvita Compost Maturity Test kits (Woods End Research Laboratory, Inc.) within $24 \mathrm{~h}$ of collection according to the manufacturer's instructions (47).

Compost respiration potential was estimated by measuring $\mathrm{CO}_{2}$ evolution during a 7-day sealed incubation of compost $(8 \mathrm{~g})$ in soil (50 g, dry weight basis; moisture content $220 \mathrm{~g} \mathrm{~kg}^{-1}$; Puyallup fine sandy loam topsoil collected from 0 to $15 \mathrm{~cm}$ depth, coarseloamy over sandy, mixed, mesic Vitrandic Haploxerolls). A 7-day incubation routinely is used to estimate decomposition rates of organic materials in soil (15). The incubation was performed at $25^{\circ} \mathrm{C}$ in sealed 0.9-liter mason jars; $\mathrm{CO}_{2}$ was collected within the mason jars in vials containing $40 \mathrm{ml}$ of $1 \mathrm{M} \mathrm{NaOH}$. For $\mathrm{CO}_{2}$ determination, the carbonate trapped in $\mathrm{NaOH}$ was precipitated with excess $\mathrm{BaCl}_{2}$, and the remaining $\mathrm{NaOH}$ was back-titrated with standardized $0.1 \mathrm{M} \mathrm{HCl}$, using phenolphthalein as the indicator (1). Compost respiration rate for the 7-day period was expressed as milligrams of $\mathrm{CO}_{2}-\mathrm{C}$ per gram of compost $\mathrm{C}$ per day, thereby correcting for differences among compost samples in moisture content and $\mathrm{C}$ concentration. Compost samples were held approximately 90 days at $4{ }^{\circ} \mathrm{C}$ prior to testing for respiration potential. Of 36 samples, 5 were excluded from respiration testing because they were not refrigerated after collection.

Microbiological populations of compost. A 10-g compost sample was added to $90 \mathrm{ml}$ of sterile $0.02 \mathrm{M}$ potassium phosphate buffer (PPB) $(\mathrm{pH} 7.0)$ in a $250-\mathrm{ml}$ flask, shaken $(300 \mathrm{rpm}$ at $25^{\circ} \mathrm{C}$ ) for $20 \mathrm{~min}$, then serially diluted in sterile $0.02 \mathrm{M}$ PPB. Dilutions were plated using an automated spiral plater (Eddy Jet; IUL Instruments, Barcelona, Spain) on selective agar and incubated at $22^{\circ} \mathrm{C}$. Bacteria were enumerated on $5 \%$ trypticase soy

TABLE 1. Compost system physical properties

\begin{tabular}{|c|c|c|c|c|c|c|c|c|}
\hline No. & $\begin{array}{l}\text { Compost } \\
\text { category }\end{array}$ & Feedstocks & $\begin{array}{l}\text { Volume } \\
\left(\mathrm{m}^{3}\right)\end{array}$ & $\begin{array}{l}\text { Turning } \\
\text { frequency }\end{array}$ & $\begin{array}{l}\text { Age } \\
\text { (days) }\end{array}$ & $\begin{array}{l}\text { Temperature } \\
\quad\left({ }^{\circ} \mathrm{C}\right)\end{array}$ & $\begin{array}{l}\text { Water content } \\
(\% \mathrm{wt} / \mathrm{wt})\end{array}$ & $\begin{array}{l}\text { Particle } \\
\text { size }^{\mathrm{x}}\end{array}$ \\
\hline 1 & Bark & Tsuga heterophylla bark & 5,000 & 0 & 125 & 44 & 50 & 62 \\
\hline 2 & Bark & Pseudotsuga menziesii bark & 13,500 & 0 & 139 & 47 & 47 & 60 \\
\hline 3 & Bark & P. menziesii bark & 1,400 & +++ & 94 & 58 & 49 & 82 \\
\hline 4 & Bark & $\begin{array}{l}\text { P. menziesii bark+gravity belt separated dairy solids } \\
(3: 1 \mathrm{vol} / \mathrm{vol})\end{array}$ & 350 & +++ & $75^{y}$ & $25^{z}$ & 52 & 66 \\
\hline 5 & Bark & $\begin{array}{l}\text { P. menziesii bark+gravity belt separated dairy solids } \\
(3: 1 \mathrm{vol} / \mathrm{vol})\end{array}$ & 1,200 & +++ & 89 & 53 & 52 & 83 \\
\hline 6 & Bark & $\begin{array}{l}\text { Mixed bark+landscape plants+biosolids } \\
\text { (proprietary ratio) }\end{array}$ & 600 & +++ & $385^{y}$ & $25^{z}$ & 62 & 82 \\
\hline 7 & Manure & Steer manure+proprietary bulking agents $(1: 1 \mathrm{vol} / \mathrm{vol})$ & 5,000 & + & 339 & 45 & 54 & 79 \\
\hline 8 & Manure & Straw, dairy manure, eggshells (20:10:1 vol/vol) & 350 & ++ & 422 & 58 & 35 & 93 \\
\hline 9 & Manure & Gravity belt separated dairy manure & 400 & + & $51^{\mathrm{y}}$ & $25^{\mathrm{z}}$ & 67 & 79 \\
\hline 10 & Manure & Gravity belt separated dairy manure & 550 & +++ & 118 & 49 & 38 & 87 \\
\hline 11 & Manure & Rice hulls+chicken manure $(3: 1 \mathrm{vol} / \mathrm{vol})$ & 300 & +++ & 118 & 44 & 26 & 85 \\
\hline 12 & Manure & Sawdust+rice hulls+chicken manure $(2: 1: 1 \mathrm{vol} / \mathrm{vol})$ & 2,100 & + & 81 & 49 & 60 & 84 \\
\hline 13 & Manure & Sawdust+rice hulls+chicken manure (2:1:1 vol/vol) & 600 & ++ & $210^{y}$ & $25^{\mathrm{z}}$ & 59 & 53 \\
\hline 14 & Manure & Sawdust+rice hulls+chicken manure (2:1:1 vol/vol) & 500 & ++ & 60 & 55 & 58 & 79 \\
\hline 15 & Manure & $\begin{array}{l}\text { Sawdust+yard trimmings+chicken manure } \\
(1: 1: 1 \mathrm{vol} / \mathrm{vol})\end{array}$ & 1,500 & 0 & 308 & 60 & 48 & 80 \\
\hline 16 & Mushroom & $\begin{array}{l}\text { Straw+chicken manure+seed meal+others } \\
\text { (proprietary blend) }\end{array}$ & 200 & +++ & 108 & 29 & 56 & 69 \\
\hline 17 & Seafood & $\begin{array}{l}\text { Sawdust+soil+fish+shrimp+crab waste } \\
(4: 1: 1: 1: 1 \mathrm{vol} / \mathrm{vol})\end{array}$ & 450 & ++ & 419 & 27 & 46 & 88 \\
\hline 18 & Vermicompost & Cow manure+food waste+paper $(1: 1: 1 \mathrm{vol} / \mathrm{vol})$ & 2 & 0 & $90^{y}$ & $25^{z}$ & 78 & 59 \\
\hline 19 & Vermicompost & Cow manure+food waste+paper $(1: 1: 1 \mathrm{vol} / \mathrm{vol})$ & 2 & 0 & 90 & 25 & 70 & 76 \\
\hline 20 & Vermicompost & Gravity belt separated dairy manure and bedding & 40 & 0 & 62 & 19 & 70 & 99 \\
\hline 21 & Vermicompost & Straw, dairy manure, eggshells (20:10:1 vol/vol) & 180 & 0 & 361 & 25 & 58 & 88 \\
\hline 22 & Nursery regrind & Ground nursery prunings and culls & 800 & Air & 168 & 32 & 55 & 69 \\
\hline 23 & Yard trimmings & Ground landscape plants & 300 & +++ & 51 & 55 & 41 & 74 \\
\hline 24 & Yard trimmings & Ground landscape plants & 300 & +++ & 44 & $\ldots$ & 49 & $\ldots$ \\
\hline 25 & Yard trimmings & Ground landscape plants & 600 & Air & 155 & 36 & 57 & 84 \\
\hline 26 & Yard trimmings & Ground landscape plants & 600 & +++ & 65 & 56 & 52 & 77 \\
\hline 27 & Yard trimmings & Ground landscape plants & 7,500 & + & 383 & 58 & 45 & 72 \\
\hline 28 & Yard trimmings & Ground landscape plants & 16,500 & + & 392 & 54 & 46 & 80 \\
\hline 29 & Yard trimmings & Ground landscape plants & 300 & +++ & 148 & 56 & 44 & 80 \\
\hline 30 & Yard trimmings & Ground landscape plants & 300 & Air & 90 & 52 & 37 & 83 \\
\hline 31 & Yard trimmings & Ground landscape plants & 600 & +++ & 79 & 29 & 50 & 73 \\
\hline 32 & Yard trimmings & Ground landscape plants & 22,000 & + & 438 & 61 & 46 & 79 \\
\hline 33 & Yard trimmings & Ground landscape plants & 20,000 & + & 193 & 49 & 29 & 69 \\
\hline 34 & Yard trimmings & Ground landscape plants & 600 & ++ & 103 & 63 & 31 & 78 \\
\hline 35 & Yard trimmings & $\begin{array}{l}\text { Ground landscape plants+chicken manure } \\
(10: 1 \mathrm{vol} / \mathrm{vol})\end{array}$ & 450 & +++ & 65 & 58 & 43 & 65 \\
\hline 36 & Yard trimmings & landscape plants+food waste $(10: 1 \mathrm{vol} / \mathrm{vol})$ & 400 & + & 500 & 39 & 40 & 51 \\
\hline
\end{tabular}

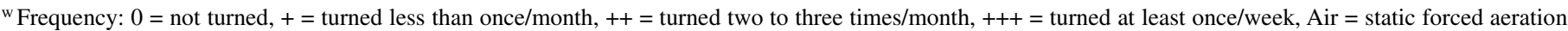
system.

${ }^{x}$ Percent passing 6.4-mm mesh sieve by wet weight.

y Compost age at sampling, stored at $4^{\circ} \mathrm{C}$, then warmed to $25^{\circ} \mathrm{C}$ over 4 days.

${ }^{\mathrm{z}}$ Compost temperature at time of analysis and pathogen bioassays. 
broth agar (TSBA; $1.5 \mathrm{~g}$ of Difco trypticase soy broth with $15 \mathrm{~g}$ of agar) with cycloheximide at $100 \mu \mathrm{g} / \mathrm{ml}$. Actinomycetes were enumerated on actinomycete isolation agar (AIA; $20 \mathrm{~g}$ of Difco actinomycete isolation agar and $5 \mathrm{ml}$ of glycerol per liter agar amended with cycloheximide at $50 \mu \mathrm{g} / \mathrm{ml}$ ). Fungi were enumerated on water agar (WA, pH 6, $18 \mathrm{~g}$ of agar/liter) amended with rifampicin at $50 \mu \mathrm{g} / \mathrm{ml}$. Yeast were enumerated on dilute, selective yeast media (SYM; $1.5 \mathrm{~g}$ of yeast extract, $2.5 \mathrm{~g}$ of peptone, $5 \mathrm{~g}$ of dextrose, $2.3 \mathrm{~g}$ of malt agar, and $17 \mathrm{~g}$ of agar/liter of agar, amended with chloramphenicol at $100 \mu \mathrm{g} / \mathrm{ml}$, ampicillin at $50 \mu \mathrm{g} / \mathrm{ml}$, streptomycin sulfate at $500 \mu \mathrm{g} / \mathrm{ml}$, and dichloran at $2 \mu \mathrm{g} / \mathrm{ml})$. Trichoderma spp. were enumerated on Trichodermaselective medium (12). Populations were recorded as CFU per dry gram of compost.

Experimental designs and statistical analysis. The dampingoff bioassays were randomized complete block experiments. For each bioassay, the number of healthy seedlings in each infested compost-amended container medium was compared with the infested peat-based standard medium; two-way analysis of variance was performed with container medium treatment and block as factors, and means were separated using Duncan's multiple range test. Disease suppression of each infested compost-amended container medium also was expressed as the percentage of the number of healthy cucumber or cabbage seedlings compared with the number of seedlings in the noninfested peat-based control medium (termed percent healthy seedlings). The percent healthy seedlings was used to determine if commercially acceptable disease control was achieved, with $80 \%$ healthy seedlings used as an arbitrary cutoff for acceptable control. For each pathogen, damping-off suppression of all compost samples was related to compost physical, chemical, and biological properties to identify factors that were predictive of disease suppression. This was done by performing linear regression analyses of individual compost physical, chemical, and biological properties (e.g., temperature, $\mathrm{pH}$, and compost respiration) against the percent healthy seedlings of all compost-amended container media.

To test the effect of volatized ammonia on seedling health, the percent healthy seedlings for each pathogen was grouped according to presence or absence of detectable ammonia volatilization. The groups were compared with a $t$ test or the Mann Whitney W test when the assumption of equality of variance could not be satisfied.

The average populations of bacteria, actinomycetes, yeast, and fungi were compared across compost categories using one-way analysis of variance. All statistics were performed with Statgraphics software (version 4.0; Manugistics Inc., Rockville, MD).

\section{RESULTS}

Most samples were grouped into four categories based on feedstocks and composting process (Table 1): bark, manure, vermicompost, and yard trimmings. Three samples, a certified-organic spent mushroom compost, a compost made with mixed seafood processing waste, and a compost made from ground plants and recycled soilless media at a commercial nursery, did not fit into a general category. Selected physical (Table 1), chemical (Table 2), and biological (Table 3) properties were determined for all samples.

Damping-off assays. Composts varied in their ability to suppress damping-off caused by Pythium spp. and $R$. solani. Compared with the infested peat-perlite medium, $67 \%$ of the compostamended container media significantly $(P<0.05)$ reduced damping-off caused by $P$. irregulare, $64 \%$ reduced damping-off caused

TABLE 2. Compost chemical properties

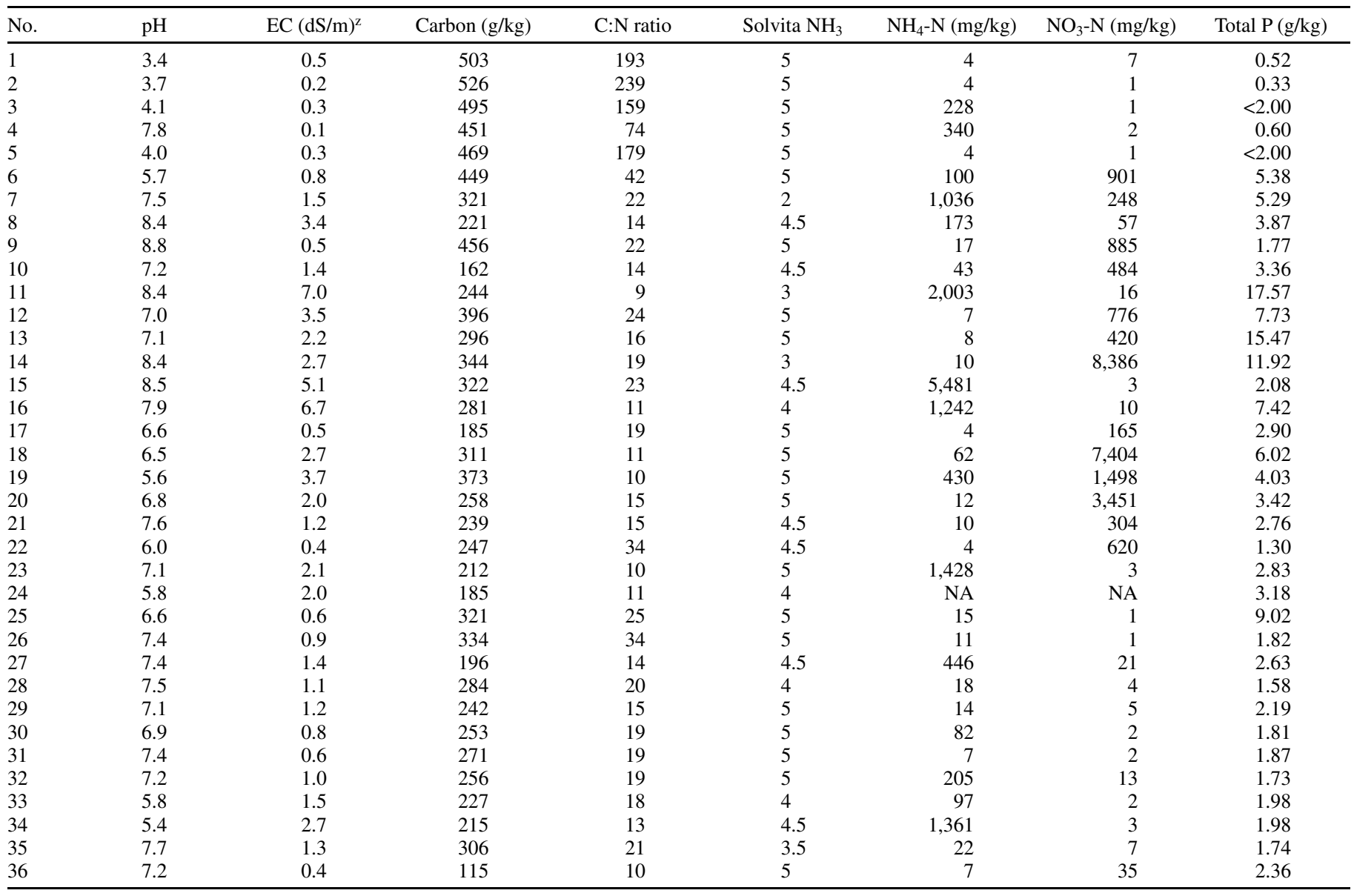

${ }^{\mathrm{z}} \mathrm{EC}=$ electrical conductivity. 
by $P$. ultimum, and $56 \%$ of the samples suppressed damping-off caused by both Pythium spp. (Table 3). Based upon the additional criterion of $80 \%$ minimum healthy seedlings needed for commercially acceptable control, $61 \%$ of the compost-amended container media effectively controlled $P$. irregulare, $53 \%$ controlled P. ultimum, and $44 \%$ effectively suppressed both Pythium spp. (Table 3 ). When mixed with peat and vermiculite, only $17 \%$ of the compost samples significantly $(P<0.05)$ reduced dampingoff caused by $R$. solani. A large portion (44\%) of the compostamended container media had significantly more damping-off caused by $R$. solani compared with the infested peat-vermiculite standard (Table 3). When the additional $80 \%$ healthy seedling criterion was applied, only $6 \%$ of the compost-amended container media effectively controlled $R$. solani. Damping-off caused by all three pathogens was significantly $(P<0.05)$ suppressed by $11 \%$ of the compost samples. Of the samples tested, $22 \%$ did not significantly suppress damping-off disease caused by any pathogen.

Compost sources that initially exhibited significant $(P<0.05)$ suppression of $R$. solani damping-off varied in both the consistency of suppression over repeat bioassays and the degree that heat treatment reduced suppressiveness. Of the six compost sources that significantly suppressed damping-off by $R$. solani, the hemlock bark, dairy fir-bark compost, mushroom compost, and nursery regrind compost, (Table 1; nos. 1, 4, 16, and 22) were consistently suppressive over three repeat bioassays (data not shown). With the exception of the hemlock bark (no. 1), the other suppressive compost sources were sampled again and treated with aerated steam (mushroom compost and nursery regrind composts not included in Table 1; dairy fir-bark compost no. 5, Table 1). Compared with unheated compost, aerated steam treatment of the mushroom and nursery regrind compost significantly $(P<0.05)$ increased disease caused by $R$. solani (Table 4$)$. Heating the dairy fir-bark compost (no. 5) did not significantly $(P<0.05)$ alter damping-off suppression (Table 4 ). However, heating the dairy fir-bark compost (no. 5) to $88^{\circ} \mathrm{C}$ had variable effects on disease suppression over three bioassays. The peat-vermiculite medium had a low level of natural suppression that was significantly $(P<$ $0.05)$ reduced in two of three aerated steam heat treatments (Table 4).

The potential of the dairy fir-bark compost to inhibit dampingoff caused by $R$. solani was enhanced by amending the compost with $T$. hamatum (T 382). Without $\mathrm{T} 382$, the dairy fir-bark media had $50 \%$ healthy cabbage seedlings. Adding T 382 to the compost immediately before use in the damping-off assay resulted in a positive but nonsignificant increase in healthy seedlings (71 versus $50 \%$, linear contrast $P=0.25$ ). Inoculating T 382 into the compost 5 days before initiating the damping-off assay significantly increased the healthy seedlings to $93 \%$ (93 versus $50 \%$, linear contrast $P=0.0004)$. The number of healthy seedlings in the inoculated and incubated treatment was not significantly dif-

TABLE 3. Compost respiration rates and damping-off suppression of compost-amended container medium against Pythium ultimum and P. irregulare on cucumber seedlings and Rhizoctonia solani on cabbage seedlings

\begin{tabular}{|c|c|c|c|c|c|}
\hline \multirow[b]{2}{*}{ No. } & \multirow[b]{2}{*}{$\mathrm{CO}_{2}$ test $^{\mathrm{y}}$} & \multirow[b]{2}{*}{ Compost respiration potential ${ }^{\mathrm{Z}}$} & \multicolumn{3}{|c|}{ Damping-off suppression ${ }^{\mathrm{x}}$} \\
\hline & & & P. ultimum & P. irregulare & R. solani \\
\hline 1 & 5 & 0.6 & $67 *$ & $80 *$ & $84 *$ \\
\hline 2 & 8 & 0.8 & 38 & $38 *$ & 15 \\
\hline 4 & 8 & 0.2 & 44 & 44 & $69^{*}$ \\
\hline 5 & 8 & 0.8 & $71 *$ & 25 & $68^{*}$ \\
\hline 6 & 8 & 0.0 & 18 & 77 & (3) \\
\hline 10 & 8 & 0.1 & 35 & 73 & (19) \\
\hline 11 & 1 & 6.7 & $80 *$ & $93^{*}$ & (33) \\
\hline 12 & 8 & 2.3 & 54 & $97 *$ & 23 \\
\hline 13 & 7 & 1.3 & $90^{*}$ & $99 *$ & (5) \\
\hline 14 & 6 & nd & $96^{*}$ & $96^{*}$ & (49) \\
\hline 15 & 5 & 6.6 & $104 *$ & $94 *$ & 11 \\
\hline 21 & 7 & 1.0 & $90^{*}$ & $84 *$ & 27 \\
\hline 22 & 2 & nd & $98 *$ & $89 *$ & $80 *$ \\
\hline 23 & 7 & 2.8 & $100 *$ & $92 *$ & (35) \\
\hline 24 & 2 & nd & $104 *$ & 96 & (41) \\
\hline 25 & 6 & 1.1 & $100 *$ & 71 & 17 \\
\hline 26 & 8 & 1.9 & $100 *$ & $88 *$ & 27 \\
\hline 27 & 7 & 1.6 & $89 *$ & $89 *$ & $(0)$ \\
\hline 28 & 8 & 1.2 & $100^{*}$ & $93^{*}$ & (0) \\
\hline 29 & 6 & 0.9 & 38 & 52 & (23) \\
\hline 30 & 8 & 0.7 & 31 & 10 & $(40)$ \\
\hline 31 & 7 & 1.6 & $96^{*}$ & $96^{*}$ & 61 \\
\hline 32 & 5 & 1.0 & $100^{*}$ & $93 *$ & 52 \\
\hline 33 & 2 & 6.3 & 55 & 29 & 62 \\
\hline 34 & 2 & 7.1 & $78^{*}$ & $80 *$ & 39 \\
\hline
\end{tabular}

${ }^{\mathrm{x}}$ Number of healthy seedlings in compost-amended container medium infested with respective pathogen, expressed as percentage of the healthy seedlings in the noninoculated peat control medium. Numbers followed by * indicate significantly less $(P<0.05)$ disease compared with infested control; means separated by Duncan's multiple range test; nd $=$ not determined. Numbers in parenthesis indicate significantly more $(P<0.05)$ disease compared with infested control, means separated by Duncan's multiple range test.

y Solvita compost maturity index.

${ }^{\mathrm{z}}$ Measured in milligrams of $\mathrm{CO}_{2}$-C per g of compost-C per day over a 7-day incubation period mixed with soil. 
ferent $(P>0.1)$ from the pathogen-free peat/vermiculite standard treatment.

Compost physical properties. At the time of sampling there was no significant relationship between disease suppression and any of the measured physical properties. For compost samples that significantly suppressed damping-off caused by Pythium spp., compost temperature was 21 to $63^{\circ} \mathrm{C}$ and compost moisture content ranged from 26 to $78 \%$ (Fig. 1A).

For compost samples that significantly suppressed damping-off caused by $R$. solani, compost temperature was 25 to $53^{\circ} \mathrm{C}$ and moisture content ranged from 50 to $56 \%$ (Fig. 1B). Damping-off suppression did not relate to compost pile volume, turning frequency, age, or particle size distribution (data not shown).

Chemical properties. Fifteen compost samples had detectable levels of ammonia volatilization with the Solvita Compost Maturity Test kits. The percent healthy seedlings of the 15 compost samples with detectable ammonia were compared with the healthy seedlings of the 21 samples without ammonia volatilization for each pathogen (Fig. 2).

For $P$. ultimum, the samples with ammonia volatilization had significantly greater median percent healthy seedlings than the median percent healthy seedlings of the non-ammonia volatizing samples $(P=0.02)$. A similar, but not statistically significant $(P=$ 0.13 ) trend was evident for median percent healthy seedlings and ammonia for $P$. irregulare (Fig. 2). There was no significant difference in the mean percent healthy seedlings between compost samples with and without ammonia volatilization for $R$. solani $(P=0.91)$.

There was no consistent relationship between compost $\mathrm{pH}, \mathrm{EC}$, and average percent healthy seedlings for each pathogen.

Compost respiration. Compost respiration, measured by Solvita compost maturity test kits, indicated that $36 \%$ of the 36 samples were in the category of lowest compost respiration, whereas $17 \%$ of the samples were in the two highest respiration categories (Fig. 3).

For Pythium spp., the percent healthy seedlings in the lowest Solvita respiration category ranged from 11 to $102 \%$; this respiration category did not separate suppressive from nonsuppressive samples (Fig. 3B and D). With the compost respiration potential method, $84 \%$ of the 31 samples tested released less than $3.0 \mathrm{mg}$ of $\mathrm{CO}_{2} / \mathrm{g}$ of compost carbon/day, whereas $16 \%$ of the samples released at least $5.0 \mathrm{mg}$ of $\mathrm{CO}_{2}-\mathrm{C} / \mathrm{g}$ of compost carbon/day (Fig. $3 \mathrm{~A}$ and $\mathrm{C}$ ). Compost respiration potential values $>1 \mathrm{mg}$ of $\mathrm{CO}_{2^{-}}$ $\mathrm{C} / \mathrm{g}$ of compost carbon/day generally suppressed Pythium damping-off (Fig. 3A and $\mathrm{C}$ ). When only the compost samples that released less than $3.0 \mathrm{mg}$ of $\mathrm{CO}_{2} / \mathrm{g}$ of compost carbon/day were considered, based on linear regression analysis there was a sig- nificant positive relationship between compost respiration potential and the average percent healthy seedlings for $P$. ultimum $(P=$ $\left.0.0001, R^{2}=0.49\right)$ and $P$. irregulare $\left(P=0.002, R^{2}=0.33\right)$.

No significant linear relationship existed between the compost respiration potential and the average percent healthy seedlings for $R$. solani $\left(P=0.80, R^{2}=0.0026\right)$, indicating that suppression was not related to total microbial activity of the composts (Fig. 3E and F).

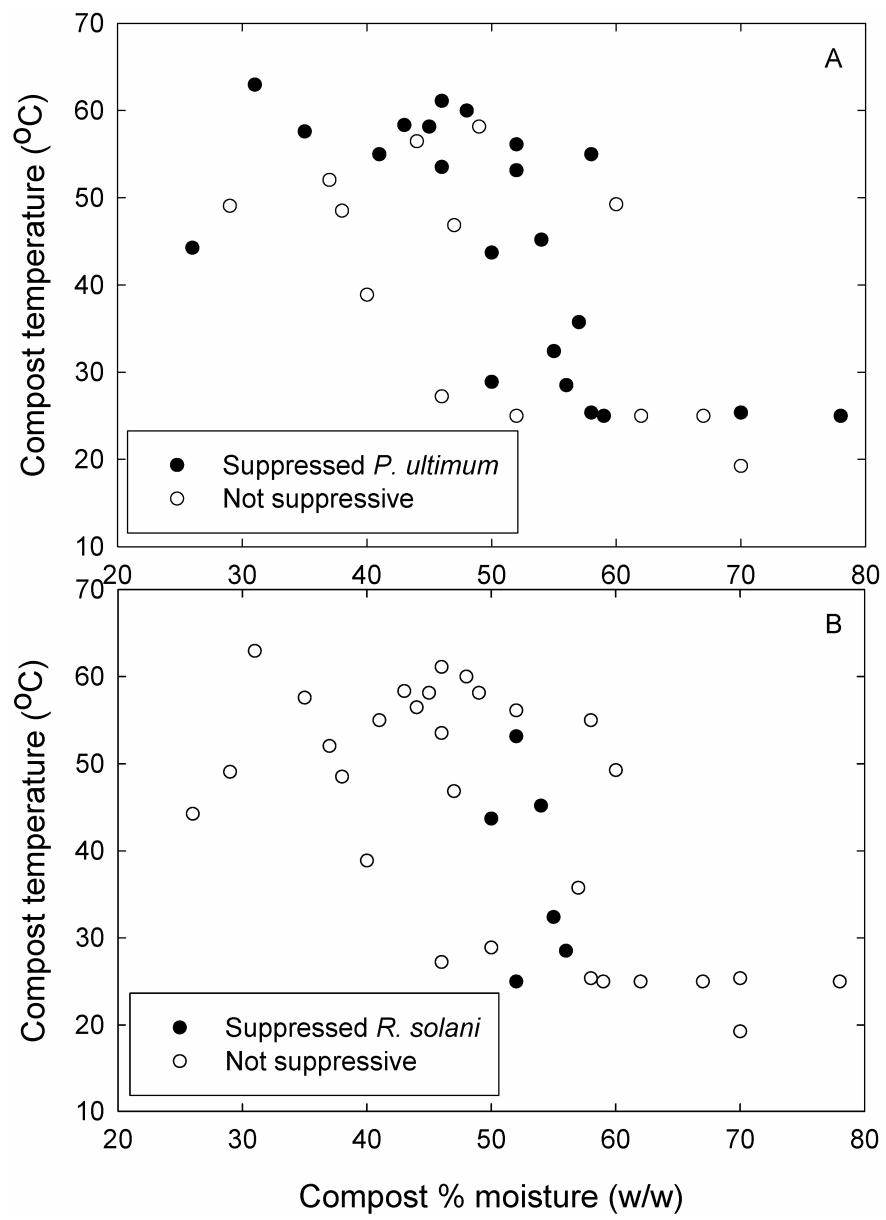

Fig. 1. Temperature and percent moisture of compost samples that significantly suppressed damping-off disease (O) or did not suppress damping-off (O) when incorporated into container media. A, Infested with Pythium ultimum and B, infested with Rhizoctonia solani.

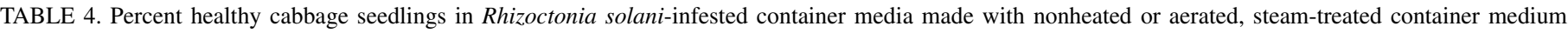
components $^{\mathrm{w}}$

\begin{tabular}{|c|c|c|c|c|c|}
\hline \multirow[b]{2}{*}{ Container media component ${ }^{\mathrm{x}}$} & \multicolumn{3}{|c|}{ Healthy cabbage seedlings $(\%)^{\mathrm{y}}$} & \multicolumn{2}{|c|}{$P$ value } \\
\hline & Not heated & $\begin{array}{c}60^{\circ} \mathrm{C} \text { aerated } \\
\text { steam }\end{array}$ & $\begin{array}{l}88^{\circ} \mathrm{C} \text { aerated } \\
\text { steam }\end{array}$ & $\begin{array}{l}\text { Not heated versus } \\
60^{\circ} \mathrm{C} \text { aerated steam }\end{array}$ & $\begin{array}{l}\text { Not heated versus } \\
88^{\circ} \mathrm{C} \text { aerated steam }\end{array}$ \\
\hline Mushroom compost & 51 & nd & 10 & $\ldots$ & 0.008 \\
\hline Mushroom compost & 92 & nd & 39 & $\ldots$ & $<0.0001$ \\
\hline Mushroom compost & 56 & 13 & 16 & $<0.0001^{\mathrm{z}}$ & $<0.0001$ \\
\hline Nursery regrind compost & 47 & nd & 4 & $\ldots$ & 0.01 \\
\hline Dairy fir-bark compost & 92 & nd & 83 & $\ldots$ & 0.46 \\
\hline Dairy fir-bark compost & 50 & 56 & 67 & 0.39 & 0.02 \\
\hline Dairy fir-bark compost & 78 & 72 & 57 & 0.35 & 0.003 \\
\hline Peat-vermiculite $(4: 1 \mathrm{vol} / \mathrm{vol})$ & 18 & nd & 2 & $\ldots$ & 0.03 \\
\hline Peat-vermiculite (4:1 vol/vol) & 30 & 12 & 29 & 0.02 & 0.88 \\
\hline
\end{tabular}

${ }^{\mathrm{w}}$ Seedlings heated with aerated steam to specified temperature for $30 \mathrm{~min}$ or not heated; nd = not determined.

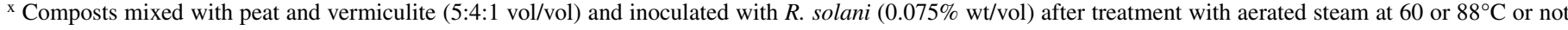
heated. Multiple row listings for the same container medium represent repeat bioassays.

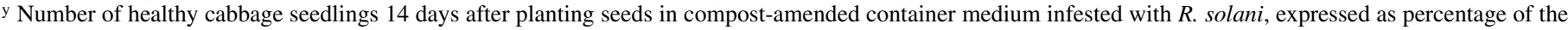
healthy seedlings in the noninfested peat control medium.

${ }^{\text {z }}$ Linear contrasts separated with Duncan's multiple range test. 
Microbial populations. One-way analysis of variance detected no significant $(P<0.05)$ difference in populations of bacteria, actinomycetes, or yeast across compost categories (Table 5). The fungal populations of the bark and vermicompost samples were significantly $(P<0.05)$ greater than in the manure or yard trimmings samples (Table 5). The population of Trichoderma spp. was significantly $(P<0.05)$ greater in the bark and vermicompost samples than in the manure samples (Table 5). There was no significant $(P<0.05)$ positive linear relationship between the population of bacteria, actinomycetes, yeast, fungi, or Trichoderma spp. and the percent healthy seedlings for any pathogen.

\section{DISCUSSION}

A majority of the compost samples significantly $(P<0.05)$ suppressed damping-off caused by $P$. irregulare and $P$. ultimum when mixed with commercial peat-perlite container medium and infested with either pathogen. Identifying suppressive compost samples using the dual criteria of having significantly more healthy seedlings than the infested control, and having at least $80 \%$ healthy seedlings compared with the noninfested control, resulted in fewer compost samples considered to be commercially viable for controlling damping-off under uniformly high disease pressure. Considering that the ultimate end user of this research is the commercial greenhouse industry, relating the number of healthy seedlings to stand counts of noninfested controls is an important parameter to report, because growers generally evaluate disease control performance in relation to ideal stand counts or yield. In addition, individual growers have different tolerances for reductions in stand count and, by reporting percent healthy seedlings in addition to statistical analyses comparing treatments to infested controls (Table 3), growers can judge effectiveness using their own criteria. For these reasons, the measurement of percent healthy seedlings was used as the response variable for regression analysis of compost physical, chemical, and biological properties.

For Pythium spp., indirectly measuring compost microbial activity with the compost respiration potential method provided more predictive information on percent healthy seedlings than determining populations of bacteria, actinomycetes, yeast, fungi,

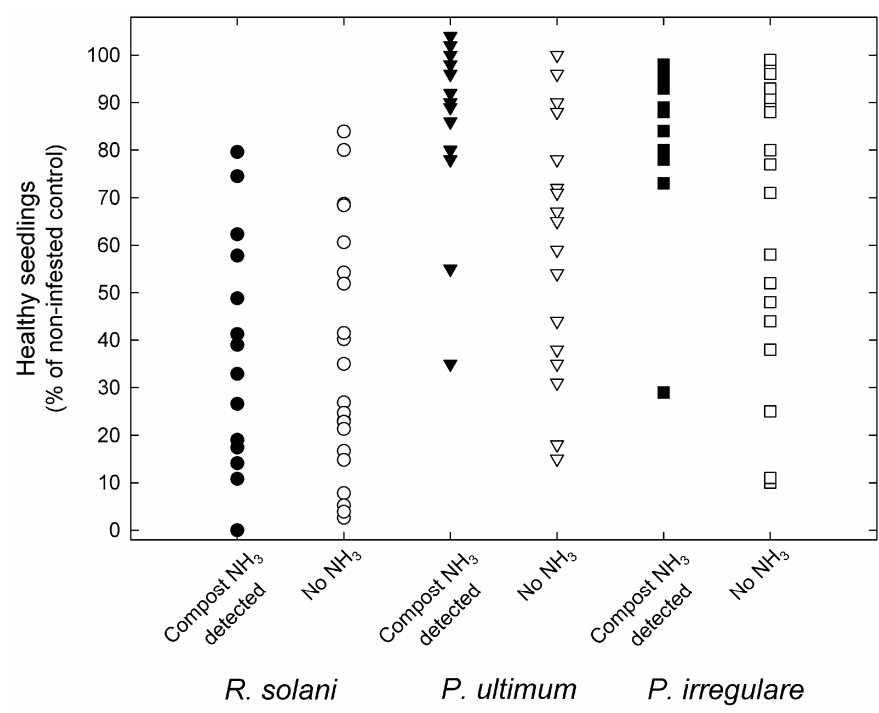

Fig. 2. Average seedling health for three damping-off pathogens in relation to compost sources that had ammonia volatilization detected verses compost samples that did not have detectable ammonia volatilization using the Solvita compost maturity test kits. Infested with Rhizoctonia solani, ammonia detected (○), ammonia not detected $(\bigcirc)$; infested with Pythium ultimum, ammonia detected (ם), ammonia not detected $(\square)$; infested with P. irregulare, ammonia detected $(\nabla)$, ammonia not detected $(\boldsymbol{\nabla})$. and Trichoderma spp. A positive linear relationship was evident between the percent healthy seedlings and compost respiration potential for the 26 compost samples that respired $<3.0 \mathrm{mg}$ of $\mathrm{CO}_{2} / \mathrm{g}$ of compost carbon/day. Although four of the five samples that respired $>5.0 \mathrm{mg}$ of $\mathrm{CO}_{2} / \mathrm{g}$ of compost carbon/day had a high degree of Pythium spp. suppression, it is appropriate to consider them separately because compost that has a relatively high respiration rate and detectable ammonia volatilization is not considered suitable for greenhouse container production (26).

In contrast to avoiding compost with excessive microbial respiration, understanding the minimum rate of compost respiration that supports suppression of damping-off could assist soilless media blenders in avoiding compost that is too stable to support biological control of Pythium spp. Based on the compost respiration potential data, a relatively small change in the potential to support microbial activity existed between nonsuppressive and suppressive composts. This is supported by the Solvita respiration data; the category of lowest respiration contained compost samples with a large range in damping-off suppression.

Similar to this study, increasing microbial activity, measured as the rate of fluorescein diacetate hydrolysis, has been positively correlated with suppression of Pythium damping-off in peat-based media $(2,25)$ and compost-amended container media $(7,10)$. For soilless container media amended with composted hardwood bark, Chen and coworkers (5) reported a minimum rate of fluorescein diacetate hydrolysis and minimal level of microbial biomass needed for predictable suppression of P. ultimum. More recently, the potential for organic matter to support suppression of Pythium damping-off has been related to the substrate biological energy availability using carbon ${ }^{13}$ cross-polarization magic angle spinning nuclear magnetic resonance spectroscopy and diffuse reflectance Fourier transform infrared spectroscopy $(3,43)$. These methods require laboratory equipment not readily available to compost producers and users; a more accessible and cost-effective method for the industry is needed. Evidence is provided here that compost respiration can be related to the potential for Pythium damping-off suppression; however, a more accurate quantitative measurement of compost respiration than was used in this study is needed to understand the transition from suppressive to conducive compost.

For Pythium spp., damping-off suppression did not relate to compost moisture, temperature, or other physical properties. Because most of the compost facilities surveyed relied on temperature and moisture data to determine when material was ready for sale (data not shown), it is important to convey that these measurements were not sufficient for predicting Pythium damping-off suppression. Of the chemical properties examined, compost samples with detectable ammonia volatilization had significantly $(P<0.05)$ greater suppression of damping-off caused by $P$. ultimum than compost samples that did not have detectable levels of ammonia volatilization. A graphically similar, but not statistically significant, trend was observed for $P$. irregulare. Compared with $P$. ultimum, $R$. solani damping-off did not relate to compost ammonia volatilization. It has been demonstrated that in vitro growth of $R$. solani is less sensitive to ammonia than P. ultimum (24). Damping-off caused by Pythium spp. is known to be suppressed by increasing the concentration of ammonia in field soil $(8,33)$. Ammonia was suggested as a probable mechanism of turkey litter compost suppressing damping-off of creeping bent grass caused by $P$. graminicola (10). Further investigation is needed to determine the potential for ammonia in compost to suppress Pythium spp. However, the use of compost-amended soilless media containing sufficient ammonia to suppress Pythium spp. might have limited practical utilization in greenhouse plant production due to ammonia phytotoxicity concerns (41).

Damping-off caused by $R$. solani was suppressed by only $17 \%$ of the compost samples, whereas $44 \%$ of the compost samples significantly increased disease compared with the infested peat/ 

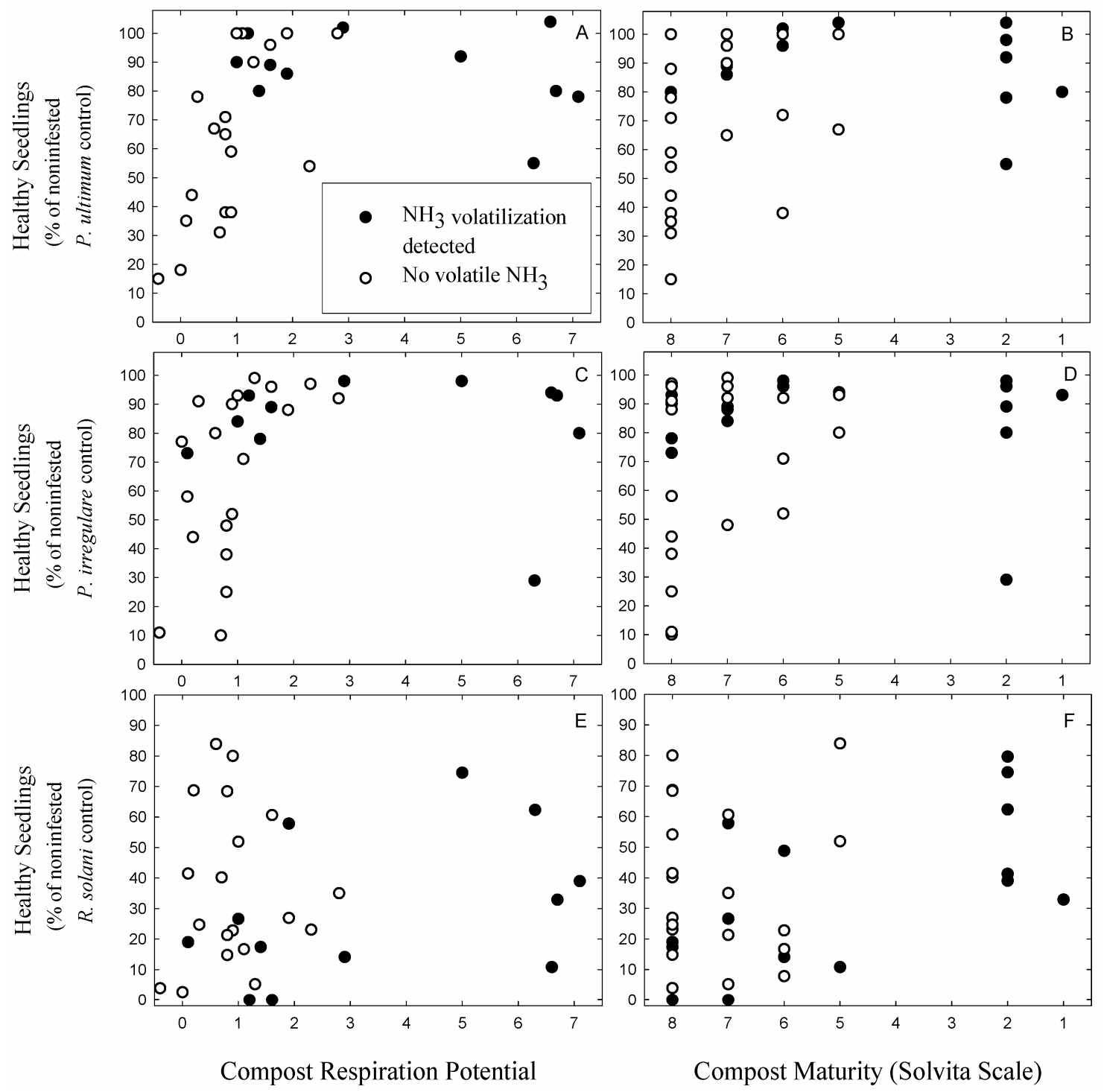

Fig. 3. Relationship of compost stability and ammonia volatilization to the percentage of healthy seedlings in pathogen-inoculated container media. Compost respiration potential determined by $\mathrm{NaOH}$ trapping $\mathrm{CO}_{2}$ released from 7-day incubation of $8 \mathrm{~g}$ of compost with $61 \mathrm{~g}$ of sandy loam soil, expressed as milligrams of $\mathrm{CO}_{2}$ released/g of compost carbon/day. Solvita scale determined by the Solvita compost maturity test kit that integrates compost respiration rate and ammonia release and is inversely proportional to the rate of compost respiration and/or ammonia release. Ammonia $\left(\mathrm{NH}_{3}\right)$ volatilization detected $(\mathbf{O})$ from compost samples with Solvita compost maturity test kits (2.0 to 4.5, Solvita scale) and ammonia volatilization not detected (O). A to D, Healthy seedlings mean of six pots, each with eight cucumber seed. Container media (compost mixed with peat/perlite, Sunshine Mix \#1; Sungro Horticulture, 1:1 vol/vol) infested with labeled Pythium spp. E and F, Healthy seedlings mean of four plug flat trays, each with 24 cabbage seed. Container media (compost mixed with peat and vermiculite, 5:4:1 $\mathrm{vol} / \mathrm{vol}$ ) inoculated with Rhizoctonia solani.

TABLE 5. Microbial populations by compost categoryt

\begin{tabular}{|c|c|c|c|c|c|c|}
\hline Compost type & $n^{\mathrm{u}}$ & Bacteria $^{v}$ & Actinomycetes ${ }^{w}$ & Yeast $^{\mathrm{x}}$ & Fungi ${ }^{y}$ & Trichoderma $^{z}$ \\
\hline Bark & 6 & $7.5 \pm 1.2 \mathrm{a}$ & $7.0 \pm 1.0 \mathrm{a}$ & $4.8 \pm 2.0 \mathrm{a}$ & $6.7 \pm 0.6 \mathrm{a}$ & $4.6 \pm 1.9 \mathrm{a}$ \\
\hline Vermicompost & 4 & $8.2 \pm 0.8 \mathrm{a}$ & $8.1 \pm 0.7 \mathrm{a}$ & $5.2 \pm 1.5 \mathrm{a}$ & $5.7 \pm 0.7 \mathrm{a}$ & $4.8 \pm 1.1 \mathrm{a}$ \\
\hline Mushroom & 1 & 10.14 & 10.05 & 6.19 & 4.96 & 4.70 \\
\hline Nursery regrind & 1 & 9.42 & 9.09 & 6.80 & 6.99 & 3.25 \\
\hline Seafood & 1 & 6.82 & 6.34 & 2.30 & 4.13 & 4.56 \\
\hline
\end{tabular}

${ }^{\mathrm{t}} \mathrm{CFU}\left(\log _{10} /\right.$ dry g of compost), mean \pm standard deviation. Numbers in each column followed by the same letter are not significantly different according to Duncan's multiple range test, $P=0.05$.

u Number of compost samples.

${ }^{v}$ Enumerated on $5 \%$ trypticase soy broth agar with cycloheximide at $100 \mu \mathrm{g} / \mathrm{ml}$

${ }^{\mathrm{w}}$ Enumerated on actinomycete isolation agar (AIA, $20 \mathrm{~g}$ of Difco actinomycete isolation agar, $5 \mathrm{ml}$ of glycerol/liter of medium, amended with cycloheximide at $50 \mu \mathrm{g} / \mathrm{ml}$.

${ }^{\mathrm{x}}$ Enumerated on dilute, selective yeast media (SYM; $1.5 \mathrm{~g}$ of yeast extract, $2.5 \mathrm{~g}$ of peptone, $5 \mathrm{~g}$ of dextrose, $2.3 \mathrm{~g}$ of malt agar, $17 \mathrm{~g}$ of agar/liter of medium, amended with chloramphenicol at $100 \mu \mathrm{g} / \mathrm{ml}$, ampicillin at $50 \mu \mathrm{g} / \mathrm{ml}$, streptomycin sulfate at $500 \mu \mathrm{g} / \mathrm{ml}$, and dichloran at $2 \mu \mathrm{g} / \mathrm{ml}$ ).

${ }^{y}$ Enumerated on water agar (WA, pH 6,18 g of agar/liter) with rifampicin at $50 \mu \mathrm{g} / \mathrm{ml}$.

${ }^{\mathrm{z}}$ Enumerated on Trichoderma-selective media (11). 
vermiculite medium. The percent healthy seedlings did not significantly $(P<0.05)$ relate to any of the physical, chemical, or biological measurements. Additionally, $R$. solani damping-off did not correlate to total microbial activity (Fig. 3E and F) or culturable populations of bacteria, actinomycetes, yeast, fungi, or Trichoderma spp. (data not shown). This agrees with results from container media amended with composted pine bark (28) and mature composted hardwood bark $(31,36)$; suppression of $R$. solani was not related to the general microflora populations, but rather corresponded to populations of specific antagonistic fungal and bacterial species $(28,31,36)$. When suppression of Rhizoctonia damping-off was positively correlated to an increase in the total microbial activity of compost-amended container medium (11), the authors also associated suppression with increases in microbial diversity and specific microbial populations, such as fluorescent pseudomonads. This exemplifies the difficulty of partitioning the mechanisms of suppression between elevated total microbial activity and increased activity of specific microbial antagonists operating in an environment of increasing nutrient competition.

Clearly, more compost samples contributed to $R$. solani's capacity to cause disease than were able to suppress the disease in relation to infested peat/vermiculite medium (Table 3). A number of factors likely were involved in the statistically greater disease observed with $44 \%$ of the composts. One factor could be due to a dilution of the peat/vermiculite media. Two of three aerated steam heat treatments significantly $(P<0.05)$ reduced damping-off suppression of the peat/vermiculite media (Table 4), indicating that the peat/vermiculite media had a naturally low level of damping-off suppression toward $R$. solani. Similarly, lightly decomposed peat has been reported to suppress $R$. solani (44).

Additionally, increased disease also could be related to the nature and quantity of decomposable substrates remaining in the compost and a modification of the physical pore matrix allowing increased hyphal extension through the medium $(18,37)$. Insufficiently cured compost can support high populations of antagonists, but saprophytic activity prevails and suppression is not induced (36). Further biochemical characterization of the composts, such as cellulose content, and determining the population dynamics of $R$. solani in the infested container media could indicate the potential for the composts to increase the population density of the pathogen (9). Increasing the inoculum density of $R$. solani from 15 to 25 propagules per $g$ in compost-amended container media has been shown to significantly increase damping-off of radish seedlings (35).

Heat treatment with aerated steam significantly reduced suppression in the mushroom and nursery regrind composts, likely indicating that damping-off suppression was biological in nature. Before sampling, these composts had cured outside, contained 45 to $56 \%$ moisture, and were below $33^{\circ} \mathrm{C}$. These curing conditions are consistent with other investigations that have concluded that maintaining moisture between 45 and $55 \%$, compost temperatures $<40^{\circ} \mathrm{C}$, and curing compost outdoors are optimal for natural biological suppression of $R$. solani to develop $(11,23,29,30)$.

Heat treatment inconsistently affected suppression in the dairy fir-bark compost (no. 5), likely indicating that suppression is partially mediated by physiochemical properties. The suppressive nature of the dairy fir-bark compost was significantly increased by inoculation with T. hamatum isolate 382 ( $\mathrm{T}$ 382) and incubation for 5 days before formulating into container media. Isolate T 382 is known to suppress damping-off caused by $R$. solani; a process for the controlled amendment of T 382 during compost production to produce a product that consistently suppresses $R$. solani has been patented (20). Suppression was not significantly increased when T 382 was amended just prior to using the compost in the damping-off assay, likely indicating that the incubation period allowed for establishment of the antagonist in the already cured compost. After 5 days of incubation, extensive mycelium and green sporulation was observed around the millet $\mathrm{T}$ 382 amendment. Isolate T 382 has been demonstrated to colonize cured hardwood bark compost, yard trimmings compost, and mixed biowaste compost $(36,39)$; further investigation with composted Douglas-fir bark is warranted.

Compost-amended container media must consistently suppress damping-off and support optimal plant growth to be a viable alternative to current commercial greenhouse practices. The majority of the compost samples in this study suppressed damping-off caused by Pythium spp. when used $50 \%$ by volume in container media. For commercial application, various incorporation rates should be tested because proper physical, chemical, and biological properties of soilless container media need to be considered for optimal plant growth and disease suppression $(4,11,24)$. Optimal incorporation rates for disease suppression could be higher than ideal physical and chemical analysis would indicate for production of a particular crop and container size. Additionally, compost sources need to be individually assessed for appropriate uses and application rates because a wide range of physical, chemical, and biological properties was evident when sources were categorized based on compost feedstocks. Using commercially available compost in container media for suppression of damping-off caused by Pythium spp. should be tested on a production scale in the Pacific Northwest. For consistent suppression of $R$. solani damping-off, amendment of compost with specific microbial antagonists should be pursued.

\section{ACKNOWLEDGMENTS}

Funding for this work was provided by USDA CRIS 303-5358-22000024-00D, the Oregon Association of Nurseries, and the Oregon Department of Agriculture. We thank the compost facilities for providing compost and detailed process information; K. Sackett for providing excellent technical assistance; and J. Chaote, graduate student in Crop and Soil Science, Oregon State University, for performing the compost respiration potential test.

\section{LITERATURE CITED}

1. Anderson, J. P. E. 1982. Soil respiration (Method 41-3.2). Methods of Soil Analysis. Chemical and microbiological properties. Agronomy Monograph 9 (Part 2). American Society of Agronomy and Soil Science Society of America, Madison, WI.

2. Boehm, M. J., and Hoitink, H. A. J. 1992. Sustenance of microbial activity in potting mixes and its impact on severity of Pythium root rot of poinsettia. Phytopathology 82:259-264.

3. Boehm, M. J., Wu, T., Stone, A. G., Kraakman, B., Iannotti, D. A., Wilson, G. E., Madden, L. V., and Hoitink, H. A. J. 1997. Cross-polarized magic-angle spinning 13C nuclear magnetic resonance spectroscopic characterization of soil organic matter relative to culturable bacterial species composition and sustained biological control of Pythium root rot. Appl. Environ. Microbiol. 63:162-168.

4. Borrero, C., Trillas, M. I., Ordovás, J., Tello, J. C., and Avilés, M. 2004. Predictive factors for the suppression of Fusarium wilt of tomato in plant growth media. Phytopathology 94:1094-1101.

5. Chen, W., Hoitink, H. A. J., and Madden, L. V. 1988. Microbial activity and biomass in container media for predicting suppressiveness to damping-off caused by Pythium ultimum. Phytopathology 78:1447-1450.

6. Chen, W., Hoitink, H. A. J., and Schmitthenner, A. F. 1987. Factors affecting suppression of Pythium damping-off in container media amended with composts. Phytopathology 77:755-760.

7. Chen, W. D., Hoitink, H. A. J., Schmitthenner, A. F., and Tuovinen, O. H. 1988. The role of microbial activity in suppression of damping-off caused by Pythium ultimum. Phytopathology 78:314-322.

8. Chun, D., and Lockwood, J. L. 1985. Reductions of Pythium ultimum, Thielaviopsis basicola, and Macrophomina phaseolina populations in soil associated with ammonia generated from urea. Plant Dis. 69:154158.

9. Chung, Y. R., Hoitink, H. A. J., and Lipps, P. E. 1988. Interactions between organic-matter decomposition level and soilborne disease severity. Agric. Ecosyst. Environ. 24:183-193.

10. Craft, C. M., and Nelson, E. B. 1996. Microbial properties of composts that suppress damping-off and root rot of creeping bentgrass caused by Pythium graminicola. Appl. Environ. Microbiol. 62:1550-1557. 
11. Diab, H. G., Hu, S., and Benson, D. M. 2003. Suppression of Rhizoctonia solani on impatiens by enhanced microbial activity in swine wasteamended potting mixes. Phytopathology 93:1115-1123.

12. Elad, Y., and Chet, I. 1983. Improved selective media for isolation of Trichoderma spp. or Fusarium spp. Phytoparasitica 11:55-58.

13. Erhart, E., and Burian, K. 1997. Evaluating quality and suppressiveness of Austrian biowaste composts. Compost Sci. Util. 5:15-24.

14. Gavlak, R. G., Horneck, D. A., and Miller, R. O. 1994. Plant, soil and water reference methods for the western region. Western Regional Ext. Publ. 125, University of Alaska, Fairbanks.

15. Gilmour, J. T., Clark, M. D., and Daniel, S. M. 1996. Predicting long-term decomposition of biosolids with a seven day test. J. Environ. Qual. 25:766-770.

16. Grebus, M. E., Watson, M. E., and Hoitink, H. A. J. 1994. Biological, chemical and physical properties of composted yard trimmings as indicators of maturity and plant disease suppression. Compost Sci. Util. 2:57-71.

17. Hadar, Y., and Mandelbaum, R. 1986. Suppression of Pythium aphanidermatum damping-off in container media containing composted liquorice roots. Crop Prot. 5:88-92.

18. Harris, K., Young, I. M., Gilligan, C. A., Otten, W., and Ritz, K. 2003. Effect of bulk density on the spatial organisation of the fungus Rhizoctonia solani in soil. FEMS Microbiol. Ecol. 44:45-56.

19. Hartmann, H. T., Kester D. E., and Davies, F. T. 1990. Plant Propagation Principles and Practices. Prentice Hall Career \& Technology, Englewood Cliffs, NJ.

20. Hoitink, H. A. J. 1987. Production of Disease Suppressive Compost and Microorganism Culture for Use Therein. The Ohio State University.

21. Hoitink, H. A. J., Boehm, M. J., and Hadar, Y. 1993. Mechanisms of suppression of soilborne plant pathogens in compost-amended substrates. Pages 601-621 in: Science and Engineering of Composting. H. A. J. Hoitink and H. M. Keener, eds. Renaissance Publications, Worthington, $\mathrm{OH}$.

22. Hoitink, H. A. J., and Fahy, P. C. 1986. Basis for the control of soilborne plant pathogens with composts. Annu. Rev. Phytopathol. 24:93-114.

23. Hoitink, H. A. J., Krause, M. S., Han, D. Y., and De Ceuster, T. J. J. 1998. Soil organic matter quality and induced resistance of plant root rots and foliar diseases. Comb. Proc. Int. Plant Prop. Soc. 48:361-367.

24. Howell, C. R., Beier, R. C., and Stipanovic, R. D. 1988. Production of ammonia by Enterobacter cloacae and its possible role in the biological control of Pythium preemergence damping-off by the bacterium. Phytopathology 78:1075-1078.

25. Inbar, Y., Boehm, M. J., and Hoitink, H. A. J. 1991. Hydrolysis of fluorescein diacetate in sphagnum peat container media for predicting suppressiveness to damping-off caused by Pythium ultimum. Soil. Biol. Biochem. 23:479-483.

26. Inbar, Y., Chen, Y., and Hoitink, H. A. J. 1993. Properties for establishing standards for utilization of composts in container media. Pages 601-621 in: Science and Engineering of Composting. H. A. J. Hoitink and H. M. Keener, eds. Renaissance Publications, Worthington, $\mathrm{OH}$.

27. Ko, W., and Hora, F. K. 1971. A selective medium for the quantitative determination of Rhizoctonia solani in soil. Phytopathology 61:707-710.

28. Krause, M. S., Madden, L. V., and Hoitink, H. A. J. 2001 Effect of potting mix microbial carrying capacity on biological control of Rhizoctonia damping-off of radish and Rhizoctonia crown and root rot of poinsettia. Phytopathology 91:1116-1123.

29. Kuter, G. A., Hoitink, H. A. J., and Chen, W. 1988. Effects of municipal sludge compost curing time on suppression of Pythium and Rhizoctonia diseases of ornamental plants. Plant Dis. 72:751-756.
30. Kuter, G. A., Nelson, E. B., Hoitink, H. A. J., and Madden, L. V. 1983. Fungal populations in container media amended with composted hardwood bark suppressive and conducive to Rhizoctonia damping-off. Phytopathology 73:1450-1456.

31. Kwok, O. C. H., Fahy, P. C., Hoitink, H. A. J., and Kuter, G. A. 1987. Interactions between bacteria and Trichoderma hamatum in suppression of Rhizoctonia damping-off in bark compost media. Phytopathology 77:1206-1212

32. Leege, P. B., and Thompson, W. H. 1997. Test Methods for the Examination of Composting and Compost. U.S. Composting Council, Bethesda, MD.

33. Lin, Y. S., Sun, S. K., Hsu, S. T., and Hsieh, W. H. 1990. Mechanisms involved in the control of soil-borne plant pathogens by S-H Mixture. Pages 249-259 in: Biological Control of Soil-Borne Plant Pathogens. D. Hornby, ed. CAB International, Wallingford, UK

34. Mandelbaum, R., Hadar, Y., and Chen, Y. 1988. Composting of agricultural wastes for their use as container media: Effect of heat treatments on suppression of Pythium aphanidermatum and microbial activities in substrates containing compost. Biol. Wastes 26:261-274.

35. Nelson, E. B., and Hoitink, H. A. J. 1982. Factors affecting suppression of Rhizoctonia solani in container media. Phytopathology 72:275-279.

36. Nelson, E. B., Kuter, G. A., and Hoitink, H. A. J. 1983. Effects of fungal antagonists and compost age on suppression of Rhizoctonia damping-off in container media amended with composted hardwood bark. Phytopathology 73:1457-1462.

37. Otten, W., Gilligan, C. A., Watts, C. W., Dexter, A. R., and Hall, D. 1999. Continuity of air-filled pores and invasion thresholds for a soilborne fungal plant pathogen, Rhizoctonia solani. Soil Biol. Biochem. 31:18031810.

38. Ringer, C. E., Millner, P. D., Teerlinck, L. M., and Lyman, B. W. 1997. Suppression of seedling damping-off disease in potting mix containing animal manure compost. Compost Sci. Util. 5:6-14.

39. Ryckeboer, J., Vaes, K., Vanwynsberghe, L., and Coosemans, J. 2002. The suitability of mature biowaste and yard waste composts as carrier substrates for bacterial and fungal biocontrol agents. Proc. 2002 Int. Symp. Composting and Compost Util. JG Press Inc., Emmaus, PA.

40. Schüler, C., Biala, J., Bruns, C., Gottschall, R., Ahlers, S., and Vogtmann, H. 1989. Suppression of root rot on peas, beans and beet roots caused by Pythium ultimum and Rhizoctonia solani through the amendment of growing media with composted organic household waste. Phytopathol. Z. 127:227-238.

41. Schumann, A. W., and Mills, H. A. 1996. Injury of leatherleaf fern and tomato from volatized ammonia after fertilizer application. J. Plant Nutr. 19:573-593.

42. Stephens, C. T., and Stebbins, T. C. 1985. Control of damping-off pathogens in soilless container media. Plant Dis. 69:494-496.

43. Stone, A. G., Traina, S. J., and Hoitink, H. A. J. 2001. Particulate organic matter composition and Pythium damping-off of cucumber. Soil Sci. Soc. Am. J. 65:761-770.

44. Tahvonen, R. 1982. The suppressiveness of Finnish light coloured Sphagnum peat. J. Sci. Agric. Soc. Finland 54:345-356.

45. Theodore, M., and Toribio, V. 1995. Suppression of Pythium aphanidermatum in composts prepared from sugarcane factory residues. Plant Soil 177:219-223.

46. Wolffhechel, H. 1988. The suppressiveness of Sphagnum peat to Pythium spp. Acta Hortic. 221:217-222.

47. Woods End Research Laboratory. 2002. Guide to Solvita Testing for Compost Maturity Index. Available on-line (Woodsend.org, verified Oct. 1, 2002). Woods End Research Laboratory, Mt. Vernon, ME. 